\title{
Vietnamese Tourist Attraction in Term of Agro- Tourism Development, a Case Study at Tra Que Village, Quang Nam Province, Viet Nam
}

\author{
Ha Van Trung ${ }^{1}$, Suchint Simaraks ${ }^{2 *}$ \\ ${ }^{1}$ Master of Rural Development Management, Graduate School, Khon Kaen University, Khon Kaen, Thailand \\ ${ }^{2}$ Faculty of Agriculture, Khon Kaen University, Khon Kaen, Thailand
}

\begin{abstract}
Agro-tourism is a form of rural tourism that has actively developed in recent years. Tra Que Vegetable Village has developed this type of tourism to meet the needs of visitors to visit and experience. However, Vietnamese tourists to experience agrotourism here are very few. The purpose of this study is to find out and determine the level of attraction to Vietnamese tourists in agro-tourism in Tra Que vegetable village. Participants responded questionnaire of the survey in term of participation levels in agricultural activities, and assessment of service quality and tourist's satisfaction reflecting after participating in the agro-tourism experience. The results indicate that most of the tourists participate partly in agricultural activities, the quality of service is good, and the level of visitor satisfaction is high. In general, the ability to attract Vietnamese tourists to agricultural tourism is high. Increasing visitor participation in agri-tourism activities will further enhance the ability to attract Vietnamese tourists in Tra Que Vegetable Village.
\end{abstract}

Keywords:- Agro-tourism, tourist's attraction, agricultural activities, Tra Que Vegetable Village

\section{INTRODUCTION}

According to Sasu \& Epuran (2016), the number of visitors who concern about rural tourism is an ascendant tendency nowadays, and they look for a new type of ecological tourism or responsible tourism. Simultaneously, the tourists tend to pay more attention and their consideration to areas that bring unique and extraordinary experiences, authentic and specific activities, as well as primordial lifestyle. In this way, it can be avoided the globalized nature of mass tourism (Sasu, 2016). Rural tourism is increasing in the world and gaining popularity both amongst tourists (Villanueva-Álvaro, MondéjarJiménez, \& Sáez-Martínez, 2017; Shikha Kapur, 2016). Agricultural tourism growth as an inevitable trend in tourism development nowadays. It is not only bringing profits in terms of the economy, especially in the rural area but also contributing to well preserving the ecological environment.

Agro-tourism was developing in Viet Nam 15 years ago (Pham Xuan Hau, 2017). But, agro-tourism in Vietnam has not yet been developed as actively as other countries in the region and in the world. Especially, the number of tourists participating in agro-tourism still accounts a relatively small number in comparison with its potential.

Hoi An is one of the most famous tourist destinations in Vietnam. Tourists visiting Hoi An, besides visiting the old town, visitors can also experience many tourist activities in surrounding tourist spots. The most prominent activities are agro-tourism activities in Tra Que vegetable village, Cam Ha ward, Hoi An city. However, However, the number of tourists participating in tourism activities here is still very low, especially for domestic tourists.

\section{A. The study reports in agro-tourism in Viet Nam}

Vo-Tong Xuan (2005) analyzed and pointed out the changing of life among Vietnamese farmers, included agrotourism. Hau \& Tuan (2017) showed some issues about the trend of rural tourism development in Vietnam. Huong (2010) concluded that studying the concepts of agricultural tourism and rural tourism in Viet Nam and its characteristics. Ngo Kieu Oanh (2010) evaluated the attractiveness of Vietnam's agricultural tourism. Nguyen, Suwanno, Thongma \& Visuthismajarn (2018) additionally explained the resident's attitudes towards agro-tourism influences and figured out its impacts on participation in agro-tourism development in Vietnam.

In Quang Nam province, Tran, Lan \& Thuy (2012) pointed out assessment results of deploying the model traditional village combined tourism in Tra Que vegetable village in recent years and set out some measures to improve the efficiency of the model, orient development for the vegetable village in the future. Thuy (2019) asserted that the impact of community-based tourism in Hoi An in positive and negative aspects. Phu, Van, Fujiwara, \& Hoa (2018) concerned that solid waste treatment in practice in Hoi An and its impacts on the community.

\section{B. Definition of the key terms}

Agro-tourism: Barbieri and Mshenga (2008) determined that agro-tourism is any activity of attracting guests that have been developed on-farm with the intention. Maruti (2009), Marques (2006). Maruti (2009), Sasu \& Epuran (2016), Darău et al. (2010) stated that agro-tourism are agricultural activities, being organized by peasants to tourists can participate in the everyday farm chores actively, helps them remain their primary job, creating an extra source of earnings; tourists also can spend the night in the peasants' households. Dennis \& Richard (2004) asserted that agro-tourism activities included purchasing a product 
directly from a farmhouse, feeding animals on-farm, picking fruit, or overnight at a farm. It also includes activities to an understanding of the nature, culture, history, environment of the land, and people on the site (George, 2008). Bui Thi Lan Huong (2010) perceived that agrotourism as a single form of tourism based on the exploitation of agricultural production resources, the tour participants are farmers, the tourist space is a farm in the field, can cause conflicts of interest with the community.

Tourist attraction: a tourist attraction has been characterized as activities, experiences, phenomena, sense or feeling belonging, that pulls tourists with a demand to make a trip out of their residence or workplace to be satisfied (Ngwira \& Kankhuni, 2018). Tourist attractions consist of landscapes, activities, and experiences. Transportation, accommodations, and other services (e.g., restaurants) can distribute to a tourist attraction (Lew, 1987 )

\section{Research question}

Which level of participation in agricultural activities do the tourists have? And which level of satisfaction do the tourist reflect after using agro-tourism services at Tra Que?

\section{Research Objectives}

The study aims to investigate the level of tourist attraction in term of tourist participation in agro-tourism at Tra Que village.

\section{RESEARCH METHOD}

This research used a quantitative method survey of 100 Vietnamese tourists who have ever visited Tra Que village from June to July in different time of the day. Vietnamese tourists have included two types of both group tourists and individual tourists.

\section{A. Study Area}

The study was conducted at Tra Que village, Quang Nam province, Viet Nam. This village is one of tourist attraction located about $2 \mathrm{~km}$ in the Northeast of Hoi An city.

\section{B. Data Collection}

Quantitative data collection was designed for gathering information about tourist opinions about research questions. Then semi-structured interview of two groups of 15 Vietnamese tourists for 30 minutes would be conducted to check the reliability of the data that had been collected before.

\section{Data Analysis}

Descriptive statistical tools such as percentage, average, etc. were used to analyze and describe tourist' response to the tourist's participation in agricultural activities, evaluate the quality of services and the level of satisfaction in general that tourist reflects after using agrotourism services at Tra Que. The analysis was carried out using Statistical Package for Social Science (SPSS Inc., version 26)

\section{Theoretical Framework}

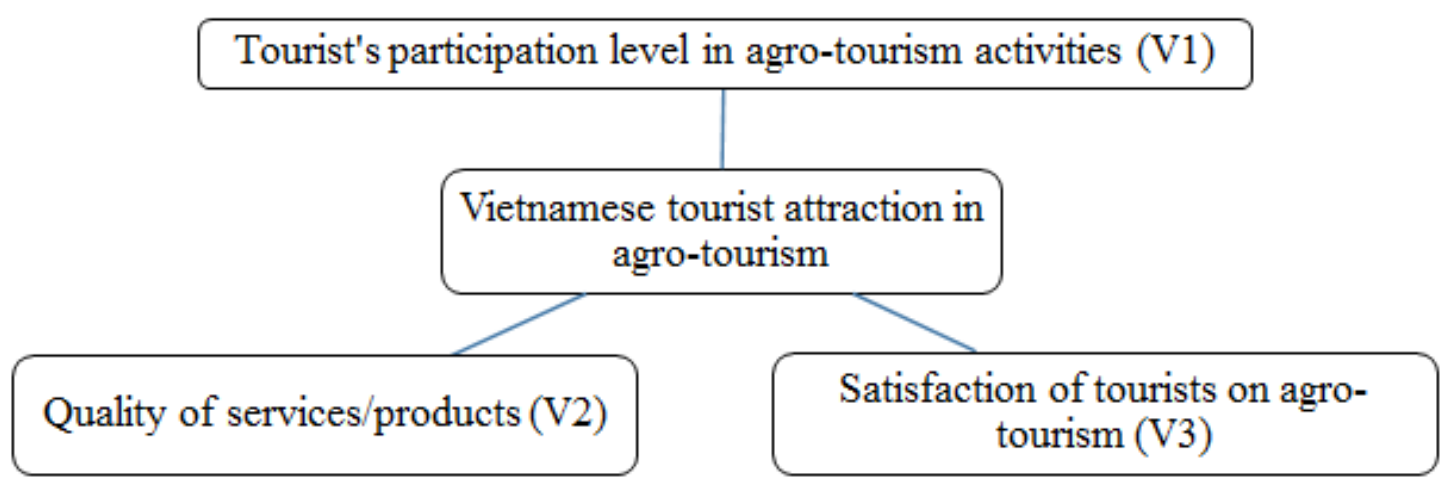

Fig 1

\section{RESULTS}

\section{A. Respondent characteristic}

\section{Gender and ages}

A survey of a quota sampling of 100 respondents who have already used the tourism services in Tra Que has been conducted to get user's opinions about agro-tourism. Among them, there are 29 males and 71 females, accounting for $29 \%$ and $71 \%$ of the whole populations, respectively. More than half of the respondents $(51 \%)$ are age from 26 to 35 years old. The respondents who are at the age of 36 to 45 years old just makeup $21 \%$ of the total. That means a majority of respondents are the young; the old rarely visit the village.

\section{Occupations}

There is approximately one-third (31\%) of respondents currently work in school and educational institutes then next to the tour guides (23\%). The respondents who work as a manager in the hotel/restaurant account for $3 \%$, businessman/businesswoman is $3 \%$, and others are 7\%. Especially, having 23 respondents among respondent currently work as tour guides account for $23 \%$. 


\section{B. Tourist's participation level in agro-tourism activities} (V1)

Many activities are serving tourists at Tra Que. Therefore, they can experience different activities on a daily trip. The activities that attracted the most visitors were vegetable growing $(75 \%)$, followed by cycling activities to visit the vegetable village (74\%), cooking class $(68 \%)$, and making rice paper $(64 \%)$. More details, almost haft of whole respondents $(48 \%)$ has ever participated partially in the growing-vegetable experience, then following next are the other activities such as making ricepaper, cooking class, cycling etc. In terms of full-time participation, cycling tour around Tra Que village (48\%) and cooking class (42\%) are activities tourist would like to participate full-time the most, then making rice-paper noodles/crackers and riding water buffaloes.

Besides, there are many unpopular activities tourists less participated in such as cooking Vietnamese rice wine (28\%), transplanting/harvesting rice $(28 \%)$, weaving things from bamboo (25\%), weaving mat $(24 \%)$. Those are unpopular activities because there are just organize in a certain period, for example, transplanting rice; or only at a few specific households remain these job, the others do not, for instance, few household produce traditional rice wine or bamboo-woven works.

\begin{tabular}{|c|c|c|c|c|c|c|c|c|c|c|c|c|c|}
\hline \multirow[b]{2}{*}{ Activities } & \multicolumn{2}{|c|}{ (1) } & \multicolumn{2}{|c|}{ (2) } & \multicolumn{2}{|c|}{ (3) } & \multicolumn{2}{|c|}{ Missing } & \multicolumn{2}{|c|}{ Total } & \multirow[b]{2}{*}{ Mean } & \multirow[b]{2}{*}{ Median } & \multirow[b]{2}{*}{ Mode } \\
\hline & $\mathrm{N}$ & $\%$ & $\mathrm{~N}$ & $\%$ & $\mathrm{~N}$ & $\%$ & $\mathrm{~N}$ & $\%$ & $\mathrm{~N}$ & $\%$ & & & \\
\hline 1. Transplanting vegetables & 19 & 19 & 48 & 48 & 27 & 27 & 6 & 6 & 100 & 100 & 2.09 & 2.00 & 2 \\
\hline 2. Weaving mat & 24 & 24 & 26 & 26 & 24 & 24 & 26 & 26 & 100 & 100 & 2.00 & 2.00 & 2 \\
\hline 3. Cooking wine & 28 & 28 & 20 & 20 & 26 & 26 & 26 & 26 & 100 & 100 & 1.97 & 2.00 & 1 \\
\hline 4. Making rice-paper & 14 & 14 & 28 & 28 & 36 & 36 & 22 & 22 & 100 & 100 & 2.28 & 2.00 & 3 \\
\hline 5. Transplanting/ harvesting rice & 28 & 28 & 22 & 22 & 26 & 26 & 24 & 24 & 100 & 100 & 1.97 & 2.00 & 1 \\
\hline 6. Bamboo weaving & 25 & 25 & 20 & 20 & 27 & 27 & 28 & 28 & 100 & 100 & 2.03 & 2.00 & 3 \\
\hline 7. Cooking class & 15 & 15 & 26 & 26 & 42 & 42 & 17 & 17 & 100 & 100 & 2.33 & 3.00 & 3 \\
\hline 8. Cycling tour & 14 & 14 & 26 & 26 & 48 & 48 & 12 & 12 & 100 & 100 & 2.39 & 3.00 & 3 \\
\hline 9. Riding water buffaloes & 23 & 23 & 27 & 27 & 31 & 31 & 19 & 19 & 100 & 100 & 2.10 & 2.00 & 3 \\
\hline 10. Others & 13 & 13 & 20 & 20 & 12 & 12 & 55 & 55 & 100 & 100 & 1.98 & 2.00 & 2 \\
\hline
\end{tabular}

Table 1:- level of tourist's participation in agricultural activities (1: Not participation, 2: partial participation, 3: full participation)

\section{Evaluation of quality of services/products (V2)}

The table 4 shows the number of respondents evaluated agro-tourism service from good and more than good account for a significant proportion. The majority number of visitors agreed that the quality of services in Tra Que is good. Notably, more than haft respondents asserted that agricultural activities and attitude of farmers toward tourists are good. They also evaluated thoroughly enjoyable about tour guide services and skills of guides, villagers and staffs on serving agro-tourism. Nobody thinks the agro-tourism in the village is of lousy quality. However, only a few respondents feel bad about the quality of infrastructure, communication \& language skills of guides, villager's attitude and behaviour, and specialization in organizing tours. In general, agro-tourism in Tra Que is highly appreciated by the good quality of activities and services that they serve to tourists. The villager and their activities accompanied by well-organized in farm activities are factors that contributed to the quality of agro-tourism in the village.

\begin{tabular}{|c|c|c|c|c|c|c|c|c|c|c|c|c|c|c|}
\hline & \multicolumn{3}{|c|}{1} & \multicolumn{2}{|c|}{2} & \multicolumn{2}{|c|}{3} & \multicolumn{3}{|c|}{4} & \multicolumn{3}{|c|}{5} & \multicolumn{2}{c|}{ Missing } & \multicolumn{2}{c|}{ Total } \\
\cline { 2 - 16 } $\begin{array}{c}\text { Evaluation } \\
\text { Units of evaluation }\end{array}$ & $\mathrm{N}$ & $\%$ & $\mathrm{~N}$ & $\%$ & $\mathrm{~N}$ & $\%$ & $\mathrm{~N}$ & $\%$ & $\mathrm{~N}$ & $\%$ & & & $\mathrm{~N}$ & $\%$ \\
\hline 1. Services (tour guides, etc) & 0 & 0 & 0 & 0 & 32 & 32 & 39 & 39 & 26 & 26 & 3 & 3 & 100 & 100 \\
\hline 2. Agricultural activities & 0 & 0 & 0 & 0 & 18 & 18 & 52 & 52 & 27 & 27 & 3 & 3 & 100 & 100 \\
\hline 3. Infrastructure & 0 & 0 & 1 & 1 & 32 & 32 & 43 & 43 & 21 & 21 & 3 & 3 & 100 & 100 \\
\hline $\begin{array}{c}\text { 4. Communication \& language skills } \\
\text { (guides, etc) }\end{array}$ & 0 & 0 & 1 & 1 & 20 & 20 & 48 & 48 & 27 & 27 & 4 & 4 & 100 & 100 \\
\hline 5. Villager's attitude and behavior & 0 & 0 & 1 & 1 & 15 & 15 & 51 & 51 & 29 & 29 & 4 & 4 & 100 & 100 \\
\hline 6. Specialization in organization & 0 & 0 & 2 & 2 & 24 & 24 & 48 & 48 & 22 & 22 & 4 & 4 & 100 & 100 \\
\hline
\end{tabular}

Table 2:- Evaluation of quality of agro-tourism services (1: Very bad, 5: Very good) 
ISSN No:-2456-2165

\begin{tabular}{|c|c|c|c|c|c|c|}
\hline & 1. Services & $\begin{array}{c}\text { Agricultural } \\
\text { activities }\end{array}$ & 3. Infrastructure & $\begin{array}{c}\text { 4. Communication } \\
\text { and language skills }\end{array}$ & $\begin{array}{c}\text { 5. Villager's } \\
\text { attitude and } \\
\text { behaviour }\end{array}$ & 6. Specialization \\
\hline Mean & 3.94 & 4.09 & 3.87 & 4.05 & 4.13 & 3.94 \\
\hline Median & 4.00 & 4.00 & 4.00 & 4.00 & 4.00 & 4.00 \\
\hline Mode & 4 & 4 & 4 & 4 & 4 & 4 \\
\hline
\end{tabular}

Table 3

\section{Evaluate satisfied of tourists on services (V3)}

Table 5 shows the level of tourists' satisfaction level among respondents who have visited Tra Que. Among tourists who have ever used services/activities, almost of them are quite satisfied with what they experienced. More details, approximately half respondents answered they quite satisfied and more of agricultural activities, tours and homestay. Also, more than half of them stated that they are satisfied and very delighted about the quality of restaurants, tour guides, tourist supported services and infrastructure. However, there are also some respondents supposed that tour guide service and tourist supported services are not excellent, and they felt unsatisfied about that.
Using Paired sample T-Test to verify the difference of average value (mean) between two groups of V2.2 Quality of agricultural activities for agro-tourism (scale from 1 to 5) and V3.4 - Satisfaction level of tourists in term of agro-tourism activities/tours ( scale from 1 to 5 ) in the same total group 100 people answered. Research results found that there is no difference in the opinion between the quality of agricultural activities and level of tourist satisfaction in terms of agricultural activities and tours $(\mathrm{p}=0.003>0.001)$ at significant level 0.001. Accordingly, most of the respondents said that the service quality of agricultural experience activities was quite good (mean of 4.21) and their satisfaction level was average (mean of 3.79).

\begin{tabular}{|c|c|c|c|c|c|c|c|c|c|c|c|c|c|c|}
\hline \multirow[b]{2}{*}{ Services/activities } & \multicolumn{2}{|c|}{1} & \multicolumn{2}{|c|}{2} & \multicolumn{2}{|c|}{3} & \multicolumn{2}{|c|}{4} & \multicolumn{2}{|c|}{5} & \multicolumn{2}{|c|}{ No answer } & \multicolumn{2}{|c|}{ Total } \\
\hline & $\mathrm{N}$ & $\%$ & $\mathrm{~N}$ & $\%$ & $\mathrm{~N}$ & $\%$ & $\mathrm{~N}$ & $\%$ & $\mathrm{~N}$ & $\%$ & $\mathrm{~N}$ & $\%$ & $\mathrm{~N}$ & $\%$ \\
\hline 1.Massage service & 2 & 2 & 1 & 1 & 16 & 16 & 25 & 25 & 5 & 5 & 51 & 51 & 100 & 100 \\
\hline 2.Homestay & 1 & 1 & 1 & 1 & 9 & 9 & 32 & 32 & 8 & 8 & 49 & 49 & 100 & 100 \\
\hline 3.Restaurant & 1 & 1 & 1 & 1 & 11 & 11 & 45 & 45 & 8 & 8 & 34 & 34 & 100 & 100 \\
\hline 4.Agricultural activities/tours & 2 & 2 & 1 & 1 & 14 & 14 & 37 & 37 & 12 & 12 & 33 & 33 & 100 & 100 \\
\hline 5. Tourguide service & 1 & 1 & 2 & 2 & 22 & 22 & 45 & 45 & 8 & 8 & 22 & 22 & 100 & 100 \\
\hline 6. Tourist supported service & 1 & 1 & 5 & 5 & 17 & 17 & 46 & 46 & 9 & 9 & 22 & 22 & 100 & 100 \\
\hline 7. Infrastructure (car park...) & 0 & 0 & 5 & 5 & 24 & 24 & 41 & 41 & 9 & 9 & 21 & 21 & 100 & 100 \\
\hline
\end{tabular}

Table 4:- Evaluation of tourist's satisfaction of agro-tourism (1: Very unsatisfied, 5: Very satisfied)

\begin{tabular}{|c|c|c|c|c|c|c|c|}
\hline & 1. Massage & 2. Homestay & 3. Restaurant & $\begin{array}{c}\text { 4. Agricultural } \\
\text { activities and } \\
\text { tours }\end{array}$ & 5. Tourguide & $\begin{array}{c}\text { 6. } \\
\text { supported service }\end{array}$ & $\begin{array}{c}\text { 7. Infrastructure } \\
\text { (Car park...) }\end{array}$ \\
\hline Mean & 3.61 & 3.88 & 3.88 & 3.79 & 3.73 & 3.73 & 3.68 \\
\hline Median & 4.00 & 4.00 & 4.00 & 4.00 & 4.00 & 4.00 & 4.00 \\
\hline Mode & 4 & 4 & 4 & 4 & 4 & 4 & 4 \\
\hline
\end{tabular}

\section{Table 5}

\section{E. Discussion, conclusion and recommendation}

The participation of Vietnamese tourists was mostly only partial, followed by full participation and nonparticipation. More details, the activities are simple but popular, time-consuming to experience, most visitors participate in a part such as vegetable growing activities. Simple, less common, and less time-consuming activities are fully engaged by visitors such as cooking, cycling, buffalo riding, bamboo weaving, and rice paper making activities. The more complicated, time-consuming, and less common activities tourists mostly do not participate in, such as wine cooking, growing and harvesting rice activities.

The majority of Vietnamese tourists rate the quality of tourism service in Tra Que to be good, which shows that at present agricultural tourism in Tra Que can serve Vietnamese tourists well. This is because Tra Que has invested a lot in local tourism development, as well as good sightseeing and experience planning for visitors, in addition 
to the standard and quality service. has made visitors enjoy while visiting here. However, some tourists did not appreciate some supportive services such as guides or the infrastructure. Therefore, Tra Que needs to consider developing infrastructure and training and developing guides in terms of qualifications and skills to better serve tourists.

Most Vietnamese tourists feel satisfied after visiting Tra Que vegetable village. This is due to the fact that the ability of tourists to meet the needs of the Tra Que vegetable village is actually higher than what tourists expected. Thus, the majority of Vietnamese tourists are quite satisfied with the services that Tra Que provides and serves tourists, but there are also a small number of tourists who are not much satisfied with the public service, tour guide and tourist support services. Although these services are less popular, they also play an equally important role in satisfying the needs of tourists.

Thus, most of the tourists participate partly in agricultural activities, the quality of service is good, and the level of visitor satisfaction is high. These evidences showed that the ability to attract Vietnamese tourists to agrotourism is quite high. However, it is necessary to further improve the ability of tourists to participate in agricultural activities to promote their exploitation in agricultural tourism development towards sustainable development.

\section{REFERENCES}

[1]. Barbieri, C., \& Mshenga, P. M. (2008). The role of the firm and owner characteristics on the performance of agritourism farms. . Sociologia Ruralis. 48 , 166-183 .

[2]. Darău, A. P., Corneliu, M., Brad, M. L., \& Avram, E. (2010). The Concept of Rural Tourism and Agritourism. . Studia Universitatis "Vasile Goldiş", Vol. 5, Nr. 1, pp.39-42.

[3]. Dennis, M., \& Richard, J. (2004). 'Agro-tourism Offers Opportunities for Farm Operators' London. Waterloo and Sons. Ltd.

[4]. Dr. Shikha Kapur ( Senior Assistant Professor Department of Adult and Continuing Education \& Extension Jamia Millia Islamia, N. D.-1. (March 2016). Rural Tourism and Economic Development: Relevance and Prospects in India.

[5]. George.H. (2008). Agritourism Enterprises on your Farm or Ranch: Where to Start. Oakland, California: UCANR Publication.

[6]. Hau, P. X., \& Tuan, V. A. (2017). The development of rural tourism in Viet Nam: objectives, practical experiences, and challenges. Journal of Science of Van Hien University, volume 5 number 2.

[7]. Huong, B. T. (January 2010). Agricultural Tourism and Rural Tourism. Scientific Research Magazine, School of Agricultural and Rural Development Managers 2, Ho Chi Minh City.

[8]. Marques, H. (2006). . Searching for complementarities between agriculture and tourismthe demarcated wine-producing regions of northern Portugal. Tourism Econ 12., 147-155.
[9]. Maruti, K. (2009). Agro-tourism: Scope and opportunities for the farmers in Maharashtra. Socio economic voice. http://www.indiastat.com/article/09/kvm/fulltext.pdf.

[10]. Nguyen, N. T., Suwann, S., Thongm, W., \& Visuthismajarn, P. (2018). The Attitudes of Residents towards Agro-tourism Impacts and Its Effects on Participation in Agro-tourism Development: The Case Study of Vietnam . African Journal of Hospitality, Tourism and Leisure, Volume 7 (4).

[11]. Pham Xuan Hau, V. A. (2017 ). The development of rural tourism in vietnam: objectives, practical experiences and challenges. Van ien university journal of science, volume 5 number 2 .

[12]. Sasu, K., \& Epuran, G. (2016). An overview of the new trends in rural tourism. Bulletin of Transilvania University of Brasov, Series V: Economic Sciences • Vol. 9 (58).

[13]. Thuy, L. T. (2018-2019). The impact of community based rural tourism on rural development, a case study of Tra Que village, Viet Nam. Khon Khaen, Thai Land: Thesis Master of Master of Rural Development, Graduate School, Khon Khaen University.

[14]. Villanueva-Álvaro, J.-J., Mondéjar-Jiménez, J., \& Sáez-Martínez, F.-J. (May 2017). Rural Tourism: Development, Management andSustainability in Rural Establishments. Sustainability, 818. 